\title{
A Study on the Relationship Between Organizational Learning and Business Model Innovation
}

\author{
Yu Zhao \\ Business School \\ Sichuan University \\ Chengdu, China
}

\author{
Xiaowen Jie* \\ Business School \\ Sichuan University \\ Chengdu, China \\ 897934166@qq.com
}

\begin{abstract}
Based on the resource-based view, this study takes the firms of Sichuan Province as research object, and conducts an empirical research on the relationship between organizational learning, resource integration capability and business model innovation. The results show that organizational learning has a significantly positive impact on resource integration capability and business model innovation. Resource integration capability is the guarantee of successful implementation of business model innovation, and plays a fully mediating role in the relationship between organizational learning and business model innovation.
\end{abstract}

Keywords-Business model innovation; Organizational learning; Resource integration capability

\section{INTRODUCTION}

In the mid 1990s, e-commerce platform built on Internet technology set up, and the academic community firstly paid attention to business models. Nowadays, Internet technology, artificial intelligence technology and large data technology have been accelerated to apply to the operation of firms. The boundaries of firms are constantly broken, and the traditional business models are changing enormously.

Foreign researches on business models have gradually matured. By contrast, the researches on business models in the Chinese context was still inadequate [1]. There was no clear explanation for the antecedent variables of business model innovation [2], and this kind of research mostly carried on the case analysis from the theoretical perspective and rarely carried on the empirical research. Therefore, it is necessary to discuss the antecedent variables of business model innovation from the empirical perspective. In addition, recent researches are concentrated on the effect of external environmental factors on business model innovation, research about the relationship between business model and the internal resources and capabilities is rare [3]. The relationship between the business model innovation and organizational learning is valuable to further study [4].

From the perspective of knowledge, organizational learning is the process of improving organizational behavior by acquiring, sharing and utilizing knowledge, thus making firms have strong innovation ability. Therefore, organizational learning plays an important role in business mode innovation. The core of business model innovation is to provide customers with valuable and innovative products or services, involving the redesign of the operation mode, business process and value creation and transmission. Organizational capacity is the key point of the successful implement of these activities. Teece put forward the concept of integration capability. It was considered that the excellent integration capability is an important factor for firms to implement business model innovation[5]. Therefore, this study aims to explore the functioning mechanism of resource integration capability in the organizational learning - business model innovation link.

\section{LITERATURE REVIEW AND HYPOTHESIS DEVELOPMENT}

\section{A. Organizational Learning and Business Model Innovation}

Huber [6] proposed that organizational learning is articulated by four constructs. which include knowledge acquisition, information distribution, information interpretation, and organizational memory. Nevis, Dibella and Gould [7] put forward that the learning process has identifiable stages, and arrives at a three-stage model: knowledge acquisition, knowledge sharing and knowledge utilization. According to previous scholars' research and combined with the needs of this research, we apply the three-stage model to define organizational learning. Organizational learning can be regarded as a dynamic process of acquiring, sharing and utilizing knowledge to develop resources and capabilities. Knowledge acquisition refers to the development or creation of technical knowledge, product knowledge, management knowledge, marketing knowledge [8]. Knowledge sharing means the dissemination of what has been learned. Knowledge utilization refers to the integration of learning so it is broadly available and be generalized to new situations [7].

Zott and Amit [9] conceptualized business model as a system of interdependent system activities that transcends the focal firm and spans its boundaries. On this basis, Amit and Zott [10] proposed the ways of business model innovation: by adding novel activities, by linking activities in novel ways, and by changing one or more parties that perform any of the activities. Teece [11] suggested that the design of a novelty business model requires creativity, insight, and information about a large number of customers, competitors and suppliers, so learning is necessary.

Guo and Zhao [12] believed that business model innovation is a process of knowledge creation and accumulation. Acquiring new knowledge and creating new knowledge is an important power source for business model innovation. Sosna and colleagues [13] argued that encouraging employees to participate in organizational decision-making only when the 
information transfer and sharing do work at various levels, forming knowledge diffusion and integration from entrepreneurs to senior management team, and then to the entire organization, which refers to promoting business model innovation. Zhao and colleagues [14] believed that firms which has a strong learning capability are associated with greater innovation. Based on this, we put forward the hypothesis:

H1: Organizational learning has a positive effect on business model innovation.

\section{B. Organizational Learning and Resource Integration Capability}

Based on resource-based view, resource integration capability refers to the dynamic ability to identify, acquire, configure and utilize the internal and external resources in order to create new resources, improve manufacturing modes, break through current thinking patterns and sustain competitive advantage [15]. Resource integration capability is a unique organizational capability, which is generated with the accumulation and allocation of resources [16]. Amit and Schoemaker [17] pointed out that resource integration capability is the unique ability based on knowledge and information to deal with the complex relationship between resources. Cao and Wang [18] pointed out that organizational learning has a positive impact on resource integration capability. Guo [19] believed that the new combination of resources requires organize a large amount of accumulated knowledge acquired through organizational learning. Based on this, we put forward the hypothesis:

$\mathrm{H} 2$ : organizational learning has a positive effect on resource integration capability.

\section{The Intermediary Role of Resource Integration Capability}

Zott, Amit and Massa [2] proposed that business model innovation, aiming at higher value and interest, is a systematically innovation activity by innovation and reformation of a series of organizational activities and structures involved in value creation, delivery and acquisition. Business model innovation relies on the effective integration of internal and external resources to redesign the process of value creation and transfer, which conduce to create more new and valuable products or services for the customers. The firms recognize the needs of the business model innovation by organizational learning, then take the active behavior to obtain the necessary resource elements of the business model innovation and integrate and configure resources to realize the business model innovation [1]. It is not difficult to find that resource integration capability will be an important activity for organizational learning to promote business model innovation. Based on this, we put forward the hypothesis:

H3: The resource integration capability mediates the relationship between organizational learning and business mode innovation.

Based on the literature review and research hypothesis, the theoretical model is illustrated in Fig. 1.

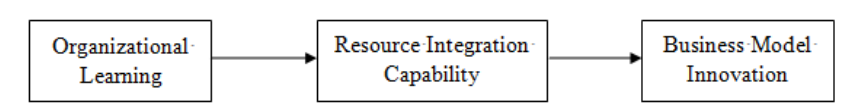

Fig. 1. Theoretical framework.

\section{RESEARCH DESIGN}

\section{A. Sample and Data Collection}

The questionnaire data for this study were gathered by surveying top and middle managers from Sichuan firms in the manufacturing or service industries using 5-point Likert Scales. In order to improve the validity of the questionnaire data, we adopted mature research scales to test key variables.

We distributed 300 questionnaires in total, these efforts finally yielded 187 responses. After deleting those with missing values or incomplete answer, we finally obtained 155 valid responses. The effective response rate was $51.67 \%$.

\section{B. Variable Measures}

This study uses the 9-item measurement of business model innovation developed by Guo and Shen [20], who refer to Shafer's concept of business model and modify the novel business model design scale of Zott and Amit. According to the research of Nevis, Dibella and Gould [7], organizational learning includes three dimension. We refer to the organizational learning scale proposed by Chen and Huang [21] and Ding [22], which consists of 10 items. The resource integration capability scale consists of 7 items referred to the scale of Zahra and Nielsen [23] and Cai and Dang [24]. We treat firm age ,size and industry type as control variables.

\section{Test of Reliability and Validity}

In this study, We apply Cronbach's alpha analysis to measure the inner stability and consistency of the Likert Scale. As is shown in Table I, the Cronbach's $\alpha$ for organizational learning, resource integration capability and business model innovation are all above 0.8 , which reflects a high level of reliability. To test whether the items suit exploratory factor analysis, we apply the KMO method and Barlett sphericity Test. Table II shows that KMO values of organizational learning, resource integration capability and business model innovation are above 0.8. Furthermore, the effect of Barlett sphericity is significant, which suggests the construct validity of the model is high.

TABLE I. CONSTRUCT RELIABILITY

\begin{tabular}{|l|l|l|}
\hline \multicolumn{1}{|c|}{ Concept } & $\begin{array}{c}\text { Number of } \\
\text { subjects }\end{array}$ & $\begin{array}{c}\text { Cronbach's } \alpha \\
\text { Coefficient }\end{array}$ \\
\hline Organizational learning & 10 & 0.895 \\
\hline Resource integration capability & 7 & 0.876 \\
\hline Business model innovation & 9 & 0.915 \\
\hline
\end{tabular}


TABLE II. CONSTRUCT VALIDITY

\begin{tabular}{|l|l|l|}
\hline \multicolumn{1}{|c|}{ Constructs } & KMO Value & $\begin{array}{c}\text { Barlett } \\
\text { Sphericity Test }\end{array}$ \\
\hline Organizational learning & 0.888 & 0.000 \\
\hline Resource integration capability & 0.869 & 0.000 \\
\hline Business model innovation & 0.914 & 0.000 \\
\hline
\end{tabular}

\section{ANALYSIS AND RESULTS}

\section{A. Descriptive Statistics and Correlations}

Before regression analysis, we carry out descriptive statistics and correlations. As Table III shows, the Spearman correlation coefficient matrix shows a significant positive correlation among organizational learning, resource integration capability and business model innovation, which provides a good basis for regression analysis. At the same time, Spearman correlation coefficients among variables are all below 0.7 , which indicates that degree of multi-collinearity of variables is low.

TABLE III. CORRELATION MATRIX

\begin{tabular}{|c|c|c|c|c|c|c|c|c|}
\hline $\begin{array}{c}\text { Varia } \\
\text { ble }\end{array}$ & $\begin{array}{c}\text { aver } \\
\text { age }\end{array}$ & S.D. & 1 & 2 & 3 & 4 & 5 & 6 \\
\hline 1.FA & $\begin{array}{l}0.49 \\
9\end{array}$ & $\begin{array}{l}0.23 \\
8\end{array}$ & 1 & & & & & \\
\hline 2.IT & $\begin{array}{l}0.65 \\
3 \\
\end{array}$ & $\begin{array}{l}0.47 \\
8 \\
\end{array}$ & $\begin{array}{l} \\
0.34\end{array}$ & 1 & & & & \\
\hline 3.FS & $\begin{array}{l}0.50 \\
4 \\
\end{array}$ & $\begin{array}{l}0.24 \\
5 \\
\end{array}$ & $\begin{array}{l}0.68 \\
5 * *\end{array}$ & $\begin{array}{l}- \\
0.35\end{array}$ & 1 & & & \\
\hline 4.OL & $\begin{array}{l}3.63 \\
0 \\
\end{array}$ & $\begin{array}{l}0.56 \\
8 \\
\end{array}$ & $\begin{array}{l} \\
0.03\end{array}$ & $\begin{array}{l}0.04 \\
2 \\
\end{array}$ & $\begin{array}{l} \\
0.04\end{array}$ & 1 & & \\
\hline 5.RIC & $\begin{array}{l}3.31 \\
5\end{array}$ & $\begin{array}{l}0.61 \\
5\end{array}$ & $\begin{array}{l}- \\
0.17\end{array}$ & $\begin{array}{l}0.07 \\
6\end{array}$ & $\begin{array}{l}- \\
0.17\end{array}$ & $\begin{array}{l}0.67 \\
6^{* *}\end{array}$ & 1 & \\
\hline $\begin{array}{l}\text { 6.BM } \\
\mathrm{I}\end{array}$ & $\begin{array}{l}3.44 \\
8\end{array}$ & $\begin{array}{l}0.65 \\
2\end{array}$ & $\begin{array}{l}0.01 \\
2\end{array}$ & $\begin{array}{l}0.11 \\
1\end{array}$ & $\begin{array}{l}0.03 \\
4\end{array}$ & $\begin{array}{l}0.49 \\
2 * *\end{array}$ & $\begin{array}{l}0.60 \\
1 * *\end{array}$ & 1 \\
\hline
\end{tabular}

${ }^{\text {a. }}$ FA-firm age; IT-industry type; FS-firm scale; OL- organizational learning; RIC- resource integration capability; BMI- business model innovation

b. ${ }^{*} p<0.05 ;{ }^{* *} p<0.01$ (two-tailed tests)

\section{B. Regression Analysis}

As Table IV shows, in Model 2 we regard business model innovation as a dependent variable and organizational learning as an independent variable. The $\beta$ index of organizational learning towards business model innovation is $0.491(\mathrm{P}<0.01)$, F equals $9.888(\mathrm{P}<0.01)$ and $\triangle \mathrm{R}^{2}$ equals 0.241 , which shows that organizational learning has a positive effects on business model innovation. Hypothesis 1 is confirmed. In Model 6 we regard resource integration capability as a dependent variable and organizational learning as an independent variable. The $\mathrm{F}$ equals $26.277, \mathrm{P}<0.01$, the $\beta$ index of organizational learning towards business model innovation is $0.670(\mathrm{P}<0.01)$, and $\triangle \mathrm{R}^{2}$ equals 0.447 , which shows that organizational learning has a positive effects on resource integration capability. Hypothesis 2 is confirmed. In Model 3 we regard business model innovation as a dependent variable and resource integration capability an independent variable. The $\mathrm{F}$ equals 18.610, $\mathrm{P}<0.01$, the $\beta$ index of organizational learning towards business model innovation is $0.626(\mathrm{P}<0.01)$, and $\triangle \mathrm{R}^{2}$ equals 0.379 , which shows that resource integration capability has a positive effects on business model innovation. We add organizational learning, resource integration capability, business model innovation and control variables to get model 4 . After adding the mediating variable into the model, the $\beta$ index between organizational learning and business model innovation declined from 0.491 $(\mathrm{P}<0.01)$ to $0.134(\mathrm{P}>0.05)$, the $\beta$ index of resource integration capability towards business model innovation is $0.534(\mathrm{P}<0.01)$. Thus resource integration capability acts as a full mediating variable between organizational learning and business model innovation. Hypothesis 3 is confirmed.

TABLE IV. REGRESSION RESULTS

\begin{tabular}{|c|c|c|c|c|c|c|}
\hline \multirow[t]{2}{*}{ DV } & \multicolumn{4}{|c|}{ Business Model Innovation } & \multicolumn{2}{|c|}{$\begin{array}{c}\text { Resource } \\
\text { Integration } \\
\text { Capability }\end{array}$} \\
\hline & M1 & M2 & M3 & M4 & M5 & M6 \\
\hline Firm age & 0.007 & 0.008 & 0.072 & 0.063 & -0.104 & -0.101 \\
\hline $\begin{array}{l}\text { Industry } \\
\text { type }\end{array}$ & 0.141 & 0.127 & 0.138 & 0.107 & 0.006 & -0.014 \\
\hline $\begin{array}{l}\text { Firm } \\
\text { size }\end{array}$ & 0.079 & 0.097 & 0.140 & 0.270 & -0.97 & -0.073 \\
\hline OL & & $\begin{array}{l}0.491 \\
* *\end{array}$ & & 0.134 & & $0.670 * *$ \\
\hline RIC & & & $\begin{array}{l}0.626 \\
* * \\
\end{array}$ & $\begin{array}{l}0.534 \\
* *\end{array}$ & & \\
\hline $\mathrm{R}^{2}$ & 0.018 & 0.259 & 0.397 & 0.407 & 0.035 & 0.482 \\
\hline $\begin{array}{l}\text { Adjust } \\
\mathrm{R}^{2}\end{array}$ & 0.007 & 0.233 & 0.376 & 0.380 & 0.009 & 0.464 \\
\hline $\mathrm{F}$ & 0.715 & $\begin{array}{l}9.888 \\
* *\end{array}$ & $\begin{array}{l}18.61 \\
0 * *\end{array}$ & $\begin{array}{l}15.36 \\
0 * *\end{array}$ & 1.372 & $\begin{array}{c}26.277^{*} \\
*\end{array}$ \\
\hline
\end{tabular}

c. OL- organizational learning; RIC- resource integration capability; BMI- business model innovation

$$
\text { d. }{ }_{p}<0.05 ; * * p<0.01 \text { (two-tailed tests) }
$$

\section{DiscUSSION}

\section{A. Conclusions}

In this study, We explore the relationship between organizational learning and business model innovation and the effect mechanism of organizational learning. Through the empirical data analysis, we come to the following conclusions.

First, organizational learning can positively influence business model innovation. Companies with a higher level of organizational learning tend to acquire kinds of knowledge from customers, competitors, partners and employees. Through knowledge flowing within the organization, the employee's personal knowledge is extended to the knowledge of the organization. Organizations can update knowledge system and break organizational inertia which is the basis for innovative activities. Therefore, organizational learning contributes to business model innovation.

Second, organizational learning can positively influence resource integration capability. In order to adapt to the changing environment, it's necessary for firms to obtain more new knowledge from the outside, absorb internalize, and utilize knowledge to solve problems. Thus firms with a higher level of organizational learning can improve the resource integration capability.

Finally, we find the $\beta$ index between organizational learning and business model innovation became not significant when adding resources integration capability into the model, thus resources integration capability fully mediates the relationship between organizational learning and business 
model innovation. Business model innovation is the innovation of system activities consisted of value acquisition and value creation. Resource integration capability, the ability to reconfigure and utilize organizational resources, is the guarantee of business model innovation. Therefore, organizational learning helps promote business model innovation by raising the resource integration capacity.

\section{B. Theoretical Contributions and Managerial Implications}

This study contributes to the theoretical developments in two ways. First, prior studies have not clearly unraveled the effect process of organizational learning and business model innovation [4], this study explores the inherent effect mechanism of organizational learning and business model innovation by introducing resources integration capability into the theoretical framework, and therefore contributes to the theoretical developments of business model innovation. Second, taking Sichuan firms in the manufacturing or service industries as the research object and introducing date into the research framework for empirical research, this paper enriches the business model research in the Chinese context.

In addition, this study has the important practice instruction significance. Resources integration capability, as an intermediate medium, is positively affecting the relationship of organizational learning and business model innovation. This shows that it is a wise choice to improve resources integration capability by organizational learning if the firm wants to implement business model innovation. Firms should actively encourage employees to obtain information and knowledge from customers, partners, competitors, and benchmarking enterprises and promote knowledge flows by a cross-section of the firm. Resources integration capability is conducive to absorb the knowledge gained from organizational learning, and therefore promote business model innovation.

\section{Limitations}

Despite the contributions of this study, there still remain some limitations. First, this study adopts a sampling method to carry out a questionnaire survey, and the subjectivity of the answer is strong. Although the reliability and validity test is carried out, there may still be a cognitive error. Second the samples only involve Sichuan province. Because of the heterogeneity of the economic development level and cultural environment in different regions of China, the validity of the conclusion in other provinces and cities needs further verification.

\section{REFERENCES}

[1] X. Wu and Z. Zhao, "The antecedents of business model innovation: research overview and prospect," Foreign Economics and Management, vol. 39, pp. 114-127, January 2017.

[2] C. Zott, R. Amit, and L. Massa, "The Business Model: Recent Developments and Future Research," Journal of Management, vol. 37, pp. 1019-1042, July 2011.

[3] C. Pang and Y. Li, "The current research situation of domestic business models, based on the analysis of CSSCI papers in 2000-2014 years," East China economic management, vol. 30, pp. 178-184, March 2016.
[4] S.C. Lambert and R.A. Davidson, "Applications of the business model in studies of enterprise success, innovation and classification: An analysis of empirical research from 1996 to 2010," European Management Journal, vol. 31, pp. 668-681, 2013.

[5] C. Zott and R. Amit, "Business model design and the performance of entrepreneurial firms," Organization Science, vol. 18, pp. 181-199, March - April 2007.

[6] G. Huber, "Organizational learning: the contributing processes and the literatures," Organization Science, vol. 2, pp. 88-115, February 1991.

[7] E.C. Nevis, A.J. Dibella, and J. M. Gould, "Understanding organizations as learning systems," Sloan Management Review, vol. 36, pp. 73-85, Winter 1995.

[8] Y. Long, Z. Li, Z. Zhang, and Y. Bi, "An empirical study on the cooperative effect of skill based strategic alliance and knowledge acquisition and learning capability," System Engineering Theory and Practice, pp. 1-7, September 2005.

[9] C. Zott and R. Amit, "Business model design: an activity system perspective," Long Range Planning, vol. 43, pp. 216-226, July 2010.

[10] R. Amit and C. Zott, "Creating value through business model innovation," Managemet Review, vol. 53, pp. 40-49, Spring 2012.

[11] D.J. Teece, "Business models, business strategy and innovation," Long Range Planning, vol. 43, pp. 172-194, 2010.

[12] Y. Guo and X. Zhao, "Business model innovation and competitive advantage from the perspective of resource-based view," Guizhou Social Sciences, vol. 234, pp. 78-82, June 2009.

[13] M. Sosna, R.N. Trevinyo-Rodríguez, and S.R. Velamuri, "Business model innovation through trial-and-error learning," Long Range Planning, vol. 43, pp. 383-407, 2010.

[14] Y. Zhao, Y. Li, S.H. Lee, and L. Chen, "Enterpreneurial orientation, organizational learning, and performance: Evidence from China," Entrepreneurship Theory and Practice, vol 35, pp. 293-317, March 2011.

[15] Z. Yi, S. Zhou, and S. Ren, "Resource integration capability and entrepreneurial performance of small and micro enterprises of science and technology," Science Research, vol. 36, pp. 123-130, January 2018.

[16] M.A. Hitt, L. Bieryian, and Z.K. Shiyii, "Direct and moderating effects of human capital onstrategy and performance in profession service firms A resource - based perspective," Academy of Management Journal, vol. 43, pp. 13-28, 2001.

[17] R. Amit and P.J.H. Schoemaker, "Strategic assets and organizational rent," Strategic Management Journal, vol 14, pp. 33-46, January 1993.

[18] H. Cao and Y. Wang, "The path of enterprise dynamic ability cultivation and promotion under the background of dynamic environment - an empirical study based on chinese high-tech enterprises," Soft Science, vol. 25, pp. 1-8, January 2011.

[19] Y. Guo, "Business model innovation and enterprise competitive advantage: internal mechanism and empirical research," Ph.D Thesis, Shanghai: Donghua University, 2009.

[20] H. Guo and R. Shen, "How to transform the entrepreneurial opportunity into enterprise performance - The intermediary role of business model innovation and the regulation of the market environment," Economic Theory and Economic Management, vol. 25, pp. 70-83, January 2014.

[21] C. Chen and J. Huang, "Strategic human resource practices and innovation performance - The mediating role of knowledge management capacity," Journal of Business Research, vol. 62, pp. 104-114, 2009.

[22] Y. Ding, "Research on the relationship between entrepreneurial organization learning and entrepreneurial performance," Ph.D Thesis, Zhejiang: Zhejiang University, 2006.

[23] S.A. Zahra and A.P. Nielsen, "Sources of capabilities, integration and technology commercialization," Strategic Management Journal, vol. 23, pp. 377-398, January 2002.

[24] J. Cai and X. Dang, "The influence of external learning on the novelty of business models: regulation of dynamic capabilities," Operations Research and Management Science, vol. 25, pp. 265-272, August 2016. 